\title{
Attitude and behavior on daily food purchasing decisions in the time of COVID- JJKo 19: A case study of Indonesia consumers \\ Widayat $^{1}$, Zainal Arifin ${ }^{2}$ \\ Faculty of Economics and Business, Universitas Muhammadiyah Malang, Indonesia ${ }^{1,2}$
}

Received: 13-04-2020 | Revision: 15-04-2020 | Accepted: 20-04-2020

\begin{abstract}
his investigation was carried out to exam the influence of attitudes towards COVID-19 with food on purchasing decisions of early adult consumers with a quantitative survey approach. The data relates to the attitude which includes that the virus is dangerous, difficult to cure and originates from China and purchasing decision behavior to fulfill daily food needs consists of being careful in choosing, paying attention to producers, care to the countries of origin, cashless payment usage, and paper money avoidance was collected with a four-scale style questionnaire distributed via Google form. Data obtained by the sample $(n=157)$ were selected using convenience methods and then analyzed by playing the Structural Equation Modeling, assisted by Smart-PLS. The result shows that attitude correlates with behavior in fulfilling daily foods. The attitudes towards the COVID-19 come from China that is dangerous, difficult to treat, contributes to cautious behavior, healthy behavior in meeting daily food needs, and purchasing payment usage. The consumer tends to the more careful in choosing, paying attention to care for the food producers, and where food comes from. Attitudes also have an impact on the preference of consumers to use E-money and paper money avoidance as an effort to avoid physical contact with the seller or supplier.
\end{abstract}

Keywords: Cashless; contactless; behavior, online; virus disease; attitude

\section{Introduction}

The Corona Virus Disease (COVID-19) outbreak began in Wuhan, China in late 2019 and spread in hundreds of countries around the world, impacting various sides of people's lives (Alon, Doepke, Olmstead-Rumsey, \& Tertilt, 2020; Meng, Hua, \& Bian, 2020). The impact of the outbreak is not only felt by business people on the side of producers, suppliers of goods or services, but also consumers. One problem affected by the virus is how consumers meet their daily food needs. What's more, Media in the world is flooded with information regarding the COVID-19 outbreak, thus cramming the cognitive apparatus of consumers. Information about the dangers of viruses which are disseminated by media can affect the consumer cognitive aspects which shape their attitudes. Attitudes toward viruses that have the potential to influence behavior. The interesting is whether consumer attitudes toward COVID-19 have an impact on their behavior in fulfilling daily foods..

At the theoretical level, attitude is the explanatory variable for behavior. This means that the attitude is correlated with behavior (Ajzen, 1993b). Theory of Planned

${ }^{1}$ widayat@umm.ac.id 
Behavior (TPB), as an extension of Theory of Reason Action (TRA), has been widely applied to explain the interrelationship between attitude and behavior (Ajzen, 1991, 1993a; Ajzen \& Fishbein, 2005). So far there have been various studies that have tried to apply the model of behavioral antecedents. For example in the study of online shopping behavior that links attitudes toward online stores with online shopping behavior (Widayat, 2018a), on environmentally friendly products influence attitudes about the green environment with the behavior of buying environmentally friendly products (Paul, Modi, \& Patel, 2016), and testing the attitudes and behaviors of using electronic money (Rahmath, Hema, Nisar, \& Abdullah, 2013), concerns which link the attitudes and behavior of consumers to healthy food products (Azzurra \& Paola, 2009) and choosing organic foods (Irianto, 2015; Wee et al., 2014), and decision making about food (Ajzen, 2015)

Empirical studies on the behavior that underlie food selection in the broad sense are not small. For example, the decision to choose a place to eat outside the home, it was found that they eat outside the house because of convenience or practicality, reasons for the gap in home-cooked menu choices, relaxation, looking for experiences, socialization with colleagues or family (N. Srividhya, 2014), wanting to enjoy food with friends or family, and relax (Ali \& Abdullah, 2012). Eating outside the house in a cafe, at a restaurant, or a certain place with the reason for relaxation enjoying being with friends, the family can indeed be done when there is no plague. However, in the event of an outbreak and the authorities ordered social distancing or physical distancing, eating out activities were severely constrained and could not be done. It also found reasons for choosing certain foods, caused by psychological, social, esteem, business and health factors(Fraikue, 2016), reasons related to diet and health (Bhurosy \& Jeewon, 2016), healthy ( Haven, 2015), biological/physiological (Symmank et al., 2017), psychological and societal factors(Vabø \& Hansen, 2014).

Besides, the demographic factors do have a part in determining the decision to choose food. In the life cycle of humans require different rations and menus. Besides, biological aspects, habits, locations where they live also contribute to determining food choices. In this paper deliberately conducted a study of young adult consumers in Indonesia. Young adult consumers have unique characteristics from the perspective of developmental psychology. Based on Piaget's four stages, the period is referred to as the formal operational period and is the final cognitive development period. At this stage, individuals move beyond concrete experiences and begin to think abstractly, reason logically and draw conclusions from available information, and apply all processes to hypothetical situations, verbal problem-solving abilities (Lefa, 2014). While Indonesia as one of the countries in the Southeast Asian region which is rich in cultural heritage (WFP, 2017), one of them is routine, staple food and has a variety of types, shapes, raw materials for staple foods.

\section{Research method}

This research plays a quantitative approach to adolescent consumers, which is the age range of 15 to 25 years. The quantitative approach is the most appropriate choice based on the objectives, namely testing the relationship of latent variable attitudes towards COVID-19 with behavior in meeting the basic needs of daily meals. Attitudes 
are measured using a scale of four (1) Strongly Agree, (2) Agree (3) Disagree and Strongly Disagree with ie COVID-19 is a dangerous (Att1_Dengerous), COVID easily cured (Att3_Easy to Cure), and COVID-19 originating from China (Att7_From China). While behavior as a latent variable is constructed with two dimensions, namely PRODUCT with an indicator (1). Manufacturer (A Food Producer), (2). Origin country (A_COC), and (3). Concern for ingredients (A Food Attention). The second dimension is the method used to get or buy food (METHOD) as measured by two indicators; (1). Avoid the use of banknotes (An Avoid Paper Money), and (2). Use of electronic money (A_E-money Usage). Primary data were obtained from respondents selected by convenience. Data collected was verified incompleteness and validity, and missing value and then treated with the Imputation Technique (Widayat, 2016). The verification results obtained complete data as many as 157 and analyzed using Partial Least Square Structural Equation Modeling (PLS-SEM), with a variety of considerations (Vinzi, W.Chin, Henseler, \& Wang, 2010; Widayat, 2018b). The use of PLS-SEM is that model tested consists of a structural model test the effect of attitude on behavior. Attitude is a first-order latent measured by formative indicators. Whereas behavior is a second-order that measured by two formative dimensions.

\section{Results and Discussion}

From available data, it can be described several demographic characteristics including gender, the last level of education, location of residence (Red Zone Area or not according to identification handling of COVID-19 outbreaks), and so on. From the aspect of the gender of respondents, men and women are almost the same, the proportions are just different $1.8 \%$, and the number of men is higher than women. Most respondents had a high school education, reaching 83 , the rest $\%$ had an education above or below high school. While viewed from the aspect of age, respondents were in the age range of 19-25 years. Most are at the age of 20 to 22 years reaching 112 (45\%). Respondents aged over 24 years were only 14 (8.8\%) people. Regarding their residence in the Red Zone, the area where there were 159 people infected with COVID-19 outbreaks from respondents, there were $79(49.7 \%)$ people living in the Red Zone area. There were some respondents namely 12 people $(7.5 \%)$ did not know whether their residence was in the red zone or not. In terms of meeting their daily food needs, most respondents (49.1\%) self-cooking, meaning that they cook themselves at home. While other respondents did it only occasionally or rarely. On the issue of buying food online, most respondents often buy online, which is $67(42 \%)$. There is a small portion of respondents namely only $5.0 \%$ who make food purchases every day online. While there are $24(15.1 \%)$ respondents have never made food purchases online. Eating out of the house is part of the lifestyle of young people, especially those who are 17-24 years old. From the sample, it was found that $68(42 \%)$ they rarely do that. But what is interesting is that some eat outside of the house every day, in a food stall or in a cafe that is as many as $28(17.6 \%)$, only a small portion is never.

The outer model is a measurement model of latent variables that are reflective or formative, at one or more levels. Table 1 shows five value criteria, namely AVE, CR, Rho_A and also Cronbach Alpha latent variables Attitudes towards COVID_19 (ATTITUDE), eating behavior (BEHAVIOR), how to get/buy (METHOD) and food 
ingredients (PRODUCT). In the outer model, the five validity criteria are greater than the acceptable minimum value $(0.50)$ and $C R$ values greater than 0.70 . This indicates that the latent variable is built with good measurements. While the latent variable ATTITUDE shows marginal measurements with marginal rho_A, CR and AVE values, and low Cronbach alpha below 0.50 (See table 1).

Table 1. Values of validity of construct latent variable

\begin{tabular}{ccccc}
\hline $\begin{array}{c}\text { Variabel } \\
\text { Latent/Dimensi }\end{array}$ & $\begin{array}{c}\text { Cronbach's } \\
\text { Alpha }\end{array}$ & rho_A & $\begin{array}{c}\text { Composite } \\
\text { Reliability }\end{array}$ & $\begin{array}{c}\text { Average } \\
\text { Variance } \\
\text { Extracted (AVE) }\end{array}$ \\
\hline ATTITUDE & $-0,191$ & 0,574 & 0,405 & 0,460 \\
BEHAVIOUR & 0,682 & 0,688 & 0,798 & 0,442 \\
METHOD & 0,724 & 0,724 & 0,879 & 0,783 \\
PRODUCT & 0,675 & 0,699 & 0,824 & 0,615 \\
\hline
\end{tabular}

Sources: Smart-PLS output

Table 2. Cross-loadings of indicators with latent variables

\begin{tabular}{|c|c|c|c|c|c|c|c|}
\hline & \multirow{2}{*}{ Indicator } & \multicolumn{2}{|r|}{ ATTITU } & \multirow[t]{2}{*}{ BEHAVI } & \multicolumn{2}{|r|}{ METH } & \multirow[t]{2}{*}{ PRODU } \\
\hline & & $\mathrm{DE}$ & OR & & OD & $\mathrm{CT}$ & \\
\hline \multirow{8}{*}{ oney } & A_Food_Producer & & 0,200 & 0,729 & & 0,247 & 0,856 \\
\hline & A_Avoide_Paper_M & & 0,132 & 0,662 & & 0,886 & 0,256 \\
\hline & A_COC & & 0,189 & 0,572 & & 0,240 & 0,627 \\
\hline & A_E-Money_Usage & & 0,089 & 0,656 & & 0,884 & 0,255 \\
\hline & A_Food_Attention & & 0,217 & 0,696 & & 0,197 & 0,847 \\
\hline & Att1_Dengerous & & 0,900 & 0,241 & & 0,167 & 0,217 \\
\hline & Att3_Easy_to_Cure & & $-0,454$ & $-0,055$ & & $-0,022$ & $-0,061$ \\
\hline & Att7_From_China & & 0,604 & 0,140 & & $-0,005$ & 0,203 \\
\hline
\end{tabular}

Sources: Smart-PLS output

Table 3. Multiple Correlation of Endogenous Variables

\begin{tabular}{lll}
\hline Latent Variables & R Square & R Square Adjusted \\
\hline BEHAVIOUR & 0,061 & 0,055 \\
METHOD & 0,555 & 0,552 \\
PRODUCT & 0,730 & 0,728 \\
\hline
\end{tabular}

Sources: Smart-PLS output

Table 2 shows the cross-loading values for all indicators used in the model. On the latent variable ATTITUDE, the value of each indicator Att1_Dengerous (0.900), Att3_Easy to cure (-0.454) and Att7_From China (0.604) is higher compared to loading on other latent variables. This indicates that the indicators are valid. While the indicators of BEHAVIOR, METHOD, and PRODUCT variables, the cross-loading value of each indicator is greater than the latent variable itself compared to other variables. This also indicates that the indicators are valid. 
Table 3 shows the R-Square values for the endogenous latent variables METHOD (0.555) and PRODUCT (0.730) are quite adequate, while the R Square Adjusted values are also equal to 0.552 and 0.728 , respectively. Meanwhile, the BEHAVIOR is a latent formative second-order formed measurement by both of these that even a small RSquare value is still worth considering.

The influence of attitude on the COVID-19 on eating behavior is set out in table 4 and visually in Figure 1 and Figure 2. In the table and figure the path coefficient (beta) is known in the path (beta) Original Sample is 0.248, the Mean Sample is 0.276 with a standard deviation of 0.075 . T statistics value of 3.290 is greater than the critical T of 1.96 and the p-value of 0.001 is smaller than 0.05 . This exposure indicates that at a $95 \%$ confidence level (Alpha $=5 \%$ ) the attitude over the COVID-19 has a significant effect on eating behavior during an outbreak. The path coefficient on the relationship between the two variables is positive. In general, these findings are consistent with the theory of planned behavior (Ajzen, 1991, 1993, 2015; Icek, 2012). In this theory, variables that precede behavior are intentions that are influenced by attitudes and subjective norms. While this paper only tests attitude variables on behavior. Research that to support the consistency of the relationship between attitude and behavior is also not small, for example, Ayudya and Wibowo (2018), Fila and Smith (2006), Hackman and Knowlden (2014), Widayat (2018), (Putra, 2016) and Rahmath, Hema, Nisar, and Abdullah (2013)

At the time of the plague, consumers were more attentive and observant in choosing the food they needed. They pay attention to the party producing the food and also from which country the food is originated. Issues suggesting that virus originally spread from China, giving rise to consumer sentiment behavior in choosing food originating from or food-producing from China. This case is very reasonable. They do not want to just because rash, do not care about the country of origin of the food they consume, they are infected by the virus. Moreover, if associated with the second attitude indicator, namely "COVID-19 is a virus that is difficult to treat/cure". This indicator is also a strong component as a constituent of attitude. The more confident consumers will be difficult to be treated or cured if infected with a virus, the behavior of consumers in choosing food will be more positive in the sense of increasingly concerned with the problem of producers, from the country. The attitude towards COVID-19, which is dangerous, thinks that the virus is not easily treated if attacked, is a component of psychological aspects that a person may feel when there is an outbreak. While eating behavior is also a psychological aspect, in this context it is measured by the attention of the producer, regardless of the country from which the food originates. If confronted with the existing empirical evidence, this study leads to the finding that psychological variables, contribute to behavioral efforts in meeting healthy eating needs as expressed by Bhurosy and Jeewon (2016), Haven (2015), Symmank et al. (2017), and also Vabø and Hansen (2014).

Tabel 4. Coefficient Beta, $t$-statistics and $p$-value of path

\begin{tabular}{cccccccc}
\hline Path Relations & $\begin{array}{c}\text { Original } \\
\text { Sample } \\
(\mathrm{O})\end{array}$ & $\begin{array}{c}\text { Sample } \\
\text { Mean (M) }\end{array}$ & $\begin{array}{c}\text { Standard } \\
\text { Deviation } \\
\text { (STDEV) }\end{array}$ & $\begin{array}{c}\text { tsStatistics } \\
(\text { IO/STDEVI) }\end{array}$ & $p$-Values \\
\hline ATTITUDE -> BEHAVIOUR & 48 & 0,2 & 0,276 & 0,075 & 3,290 & 01 & 0,0
\end{tabular}




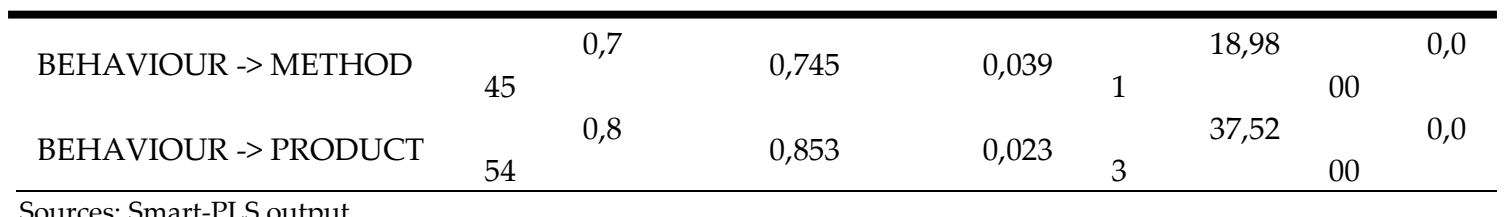

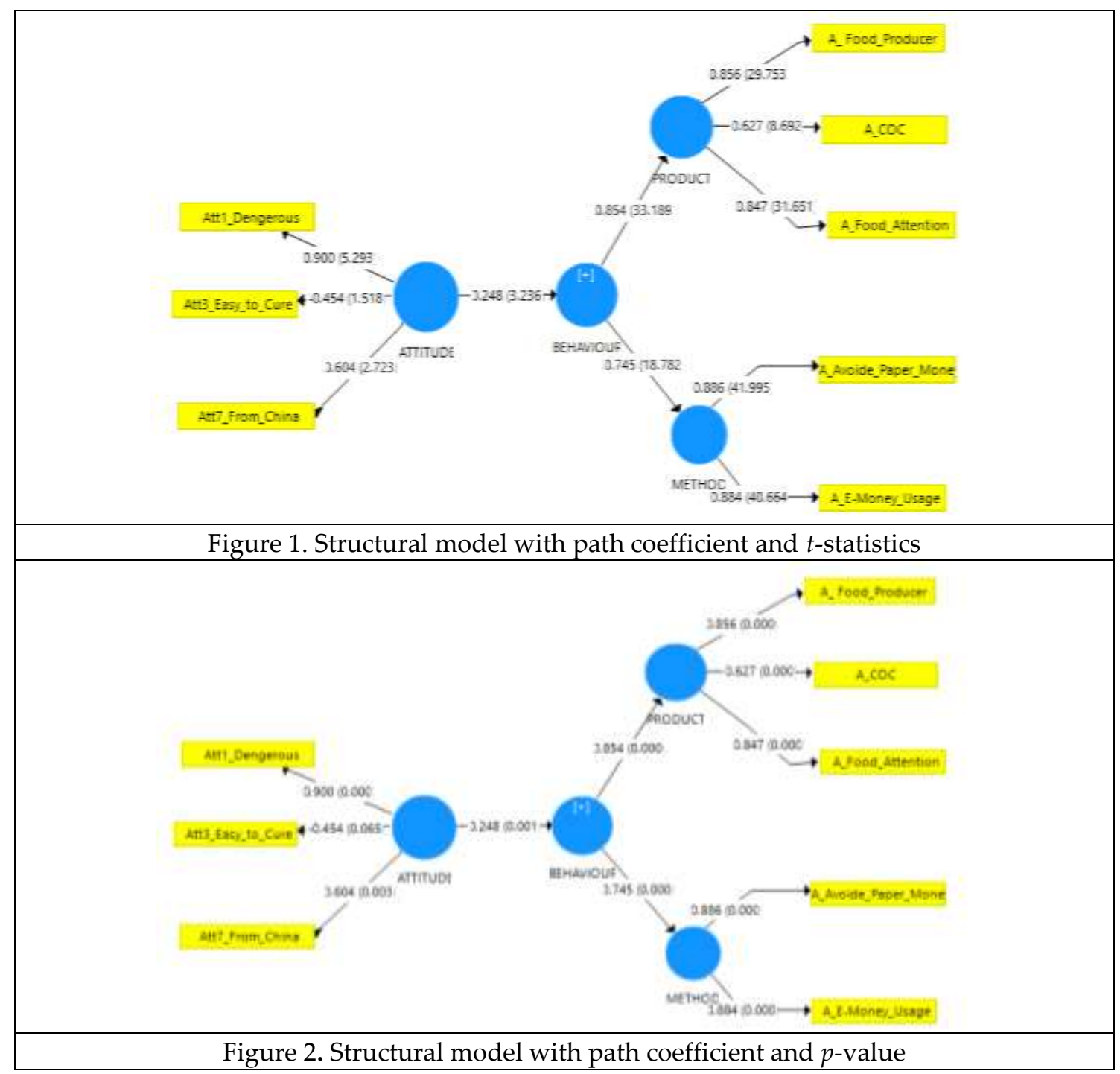

While the relationship between attitude and behavioral, for the dimensions of payment facilities consisting of an avoid Paper money, it can be interpreted that the more confident consumers are of the dangers of the COVID-19, the more they will avoid the use of banknotes for transactions and likewise, the more confident the danger of the virus will be more intensive use of electronic money (A-Emoney Usage). The empirical use of electronic money and the behavior of avoiding the use of banknotes in transactions can be confronted with the Theory of Plan Behavior. Avoiding the use of 
banknotes as an effort to not transmit viruses, and switch to electronic money, EBanking, or Internet Banking. Through the use of payment that is cashless and contactless because it hopes not contracting the virus, this finding is to have a consistency of previous research, for example, Shah Alam and Mohamed Sayuti (2011). Various media to spreading out that the virus can be through droplets, water that comes out of the mouth or nose when someone coughs, sneezes, or even talks. Behavior that is less conducive when someone coughs or sneezes, in communicating when transacting between sellers and consumers. People understand that money is a medium for transmitting viruses. Therefore, in making transactions, they tend to avoid paper money to use electronic money.

\section{Conclusions}

Attitude is a consistent predictor of behavior. The Planned Behavior Theory that was initiated by Icek Azjen is still a relevant theory to explain the latest phenomena, especially the association of attitudes towards the Novel Corona Virus Dessea 19, on eating behavior. The belief, which is a component of attitudes about viruses originating from China, is dangerous, difficult to treat, and influences consumer behavior in meeting food needs. The impact of beliefs about the virus is that consumers care or pay attention to the food products they choose, concerning the country of origin of the food producers they eat, and also food ingredients. Besides, because the virus is dangerous and difficult to treat, consumers avoid direct contact with sellers or food providers, so they use the means of payment that might avoid spreading the virus by using electronic money or avoid using paper money.

\section{References}

Ajzen, I. (1991). The theory of planned behavior. Organizational Behavior and Human Decision Processes, 50(2), 179-211. doi:10.1016/0749-5978(91)90020-t

Ajzen, I. (1993). Attitude theory and the attitude-behavior relation.

Ajzen, I. (2015). Consumer attitudes and behavior: The theory of planned behavior applied to food consumption decisions. Rivista di Economia Agraria, LXX(2), 121138. doi:10.13128/REA-18003

Ali, N., \& Abdullah, M. A. (2012). The food consumption and eating behaviour of Malaysian urbanites: Issues and concerns. GEOGRAFIA OnlineTM Malaysia Journal of Society and Space, 8(6), 157 - 165.

Alon, T., Doepke, M., Olmstead-Rumsey, J., \& Tertilt, M. (2020). The Impact of COVID19 on Gender Equality.

Ayudya, A. C., \& Wibowo, A. (2018). The Intention to Use E-Money using Theory of Planned Behavior and Locus of Control. Jurnal Keuangan dan Perbankan, 22(2), 335-349. doi:10.26905/jkdp.v22i2.1691

Bhurosy, T., \& Jeewon, R. (2016). Changes in eating habits and food traditions of IndoMauritians. Indian Journal of Traditional Knowledge, 15(3), 355-362.

Fila, S. A., \& Smith, C. (2006). Applying the Theory of Planned Behavior to healthy eating behaviors in urban Native American youth. Int J Behav Nutr Phys Act, 3, 11. doi:10.1186/1479-5868-3-11 
Fraikue, F. B. (2016). Reasons For Eating Out And Socio-Demographic Characteristics Of Customers. Paper presented at the Proceedings of INCEDI 2016 Conference I August 29-31, 2016, Accra -Ghana 651.

Hackman, C. L., \& Knowlden, A. P. (2014). Theory of reasoned action and theory of planned behavior-based dietary interventions in adolescents and young adults: a systematic review. Adolesc Health Med Ther, 5, 101-114. doi:10.2147/AHMT.S56207

Haven, A. (2015). Consumer Behavior and the Growth of the Fast Food Industry in a Small Emerging Country. International Journal of Advances in Management and Economics Available online at: www.managementjournal.info, 4 180-189.

Icek, A. (2012). The Theory of Planned Behavior. In Handbook of Theories of Social Psychology (Vol. Volume 1, pp. 438-459).

Meng, L., Hua, F., \& Bian, Z. (2020). Coronavirus Disease 2019 (COVID-19): Emerging and Future Challenges for Dental and Oral Medicine. J Dent Res, 22034520914246. doi:10.1177/0022034520914246

N. Srividhya. (2014). "Eating Out Habit of Individuals - An Analytical Study" (With Special Reference to Puducherry City). International Journal of Business and Management Invention ISSN (Online): 2319 - 8028, ISSN (Print): 2319 - 801X www.ijbmi.org Volume 3 Issue 6ll June. 2014 II PP.38-44.

Putra, D. M. (2016). The Influence On Factors In Attitudes Toward Acceptance Of The Information System Using Technology Acceptance Model (TAM) Case Study SPAN System In Indonesia. International Journal Of Scientific \& Technology Research, 5(4), 5.

Rahmath, S., Hema, D., Nisar, H., \& Abdullah, K. (2013). Combination of TAM and TPB in Internet Banking Adoption. International Journal of Computer Theory and Engineering, 146-150. doi:10.7763/ijcte.2013.V5.665

Symmank, C., Mai, R., Hoffmann, S., Stok, F. M., Renner, B., Lien, N., \& Rohm, H. (2017). Predictors of food decision making: A systematic interdisciplinary mapping (SIM) review. Appetite, 110, 25-35. doi:10.1016/j.appet.2016.11.023

Vabø, M., \& Hansen, H. (2014). The Relationship between Food Preferences and Food Choice: A Theoretical Discussion. International Journal of Business and Social Science, 5(7).

Widayat. (2016). Analisis Data Penelitian [Konsep Dan Aplikasi Pada Penelitian Kuantitatif] (Vol. 1). Malang: UMM Press.

Widayat. (2018). E-Consumer Behavior: The Roles of Attitudes, Risk Perception on Shopping Intention-Behavior. Advances in Economics, Business and Management Research, 57. 